\title{
Effect of Injection timing on diesel engine performance, combustion and emission characteristics operated with Dairy Scum Biodiesel
}

\author{
Manjunath Channappagoudra ${ }^{* \#,}$ K. Ramesh ${ }^{\#}$ and Manavendra.G^ \\ \#Department of Mechanical Engineering, U.B.D.T College of Engineering, Davangere, Karnataka, India \\ ${ }^{\wedge}$ Department of Mechanical Engineering, B.I.E.T, Davangere, Karnataka, India
}

Received 05 March 2018, Accepted 08 May 2018, Available online 12 May 2018, Vol.8, No.3 (May/June 2018)

\begin{abstract}
Treating of dairy waste scum into fuel will be the very beneficial for milk dairies in terms of energy savings, reduction of hazardous emissions and independency on foreign fuels. This new approach of developing and utilization of dairy scum oil methyl ester is highly pronounced in the field of alternative fuels for diesel engines. In the present study experimental work attempts to unfold the influence of DSOME blends and injection timing (IT) on the performance, emission and combustion characteristics of diesel engine. In the first phase of experimental work effect of different blends namely DSOME-B10, DSOME-B20, DSOME-B30 and DSOME-B100 are studied and compared with petroleum diesel. In second phase of experimental work different injection timings namely 20.deg.bTDC, 23.deg.bTDC, 26.deg.bTDC and 29.deg.bTDC are studied and compared with standard engine. From first phase of experimental works its revealed that significant improvement of brake thermal efficiency, brake specific fuel consumption and reduced $\mathrm{HC}$, CO emissions are observed for DSOME-B20 blend hence it is optimized and carried to the second phase of the work to optimize the injection timing. From second phase of experimental results it is concluded that 26.deg.bTDC IT for DSOME-B20 operation shown the improved performance, combustion and emission characteristics among other ITs hence it is optimized for DSOME-B20 fuel blend.
\end{abstract}

Keywords: Dairy scum oil methyl ester, Diesel engine, Injection timing, Performance, Combustion, Emissions

\begin{tabular}{ll}
\multicolumn{2}{l}{ Abbreviations } \\
DSOME & Dairy scum oil methyl ester (biodiesel) \\
DSOME-B10 & $10 \%$ dairy scumbiodiesel+90\% diesel \\
DSOME-B20 & $20 \%$ biodiesel+80\% diesel \\
DSOME-B30 & $30 \%$ biodiesel+70\% diesel \\
DSOME-B100 & $100 \%$ biodiesel+ $0 \%$ diesel \\
ULSD & Ultra low sulfur diesel \\
KOH & Potassium hydroxide \\
bTDC & Before top dead centre \\
IT & Injection timing \\
IOP & Injector opening Pressure \\
BTE & Brake thermal efficiency \\
BSFC & Brake specific fuel consumption \\
BMEP & Brake mean effective pressure \\
IMEP & Indicated mean effective pressure \\
EGR & Exhaust gas recirculation \\
CO & Carbon monoxide \\
HC & Hydrocarbons \\
CO & Carbon dioxide \\
NOx & Oxides of nitrogen \\
HRR & Heat release rate \\
CHRR & Cumulative heat release rate \\
\end{tabular}

*Corresponding author's ORCID ID: 0000-0002-8389-717X DOI: https://doi.org/10.14741/ijcet/v.8.3.5
RPR Rate of pressure rise

deg. Degrees

\section{Introduction}

Preservation of environment and energy resources by treating biomass waste is in too much necessity for mankind to substitute the petroleum fuels. The exhaust emissions from internal combustion engines operated with fossil fuels cause serious effect on human being since there are a lot of encouragements to search for alternative fuels which have similar properties as petro diesel. For diesel engines, a significant research effort has been directed towards using vegetable oils and their derivatives as fuels. Bio fuels such as vegetable biodiesel, ethanol, hydrogen, methane, LPG, CNG, and Producer Gas etc. are the most suitable answers to this search. Biofuel production technology integrates biomass conversion into biofuels as substitute fuels to petroleum fuels. In this regard biodiesel derived from crop based vegetable oil or animal fat oils can be consider for diesel engines as they are renewable, nontoxic, locally available and less emissions profiles. The properties of biodiesel are approximately same as the diesel fuel and it can be directly used as alternative fuel for diesel engine without any major modification 
in the engine. Biodiesel have several superior combustion characteristics compare to diesel. Hence it's suggested for fuelling the engine with biodiesel, one should go for higher compression ratio and higher injection pressure (S. Jindal et al. 2010). The oil and gas reserves would suffice to last only in few more decades which well suggested by the expert. Crop based Biorenewable oils are the main substitutes to petroleum-based gasoline and diesel fuel. The application of renewable Biohydrogen in IC engines will play the major role in future (A. DEMIRBAS.2010). Alcohol and biodiesel have been proposed as alternative fuels for IC engines. Biodiesel is renewable, nontoxic and easily biodegradable, has no aromatic compounds, and possesses a high cetane number, high flash point and also excellent lubricity performance. But have some draw backs like higher density, viscosity, cloud point, and lower heating value and volatility compare to diesel (Agarwal AK.2007).

Biodiesel can be obtained from vegetable oils like soybean, sunflower, rapeseed (canola), and safflower. The application of hazelnut oil and rapeseed oil methyl esters in existing diesel engine not required any modifications. The main demerit of biodiesel is high viscosity; it can be solved by using additives or modifying injection advance and injection pressure (Ismet Çelikten et al. 2008). There is a lot of scope for research for automotive manufacturers as the biodiesel has higher viscosity and density hence investigations on effect of fuel spray, combustion and pollution formation is needed as the higher viscosity of biodiesel tends to alter the injection spray characteristics, resulting in fuel impingement on the piston and other combustion chamber surfaces (Yoon SH et al. 2208).

For biodiesel operation emissions such as those of THCs and CO are generally found to be decrease significantly. Which is attributed to inherent presence of oxygen content in biodiesel hence it causes complete combustion (Magi'n Lapuerta et al. 2008). Biodiesel showed lower heat release rate, shorter ignition delay and slightly higher combustion duration compared to diesel and lesser HC, CO emissions. Hence, the waste cooking palm oil-based biodiesel can be used as a suitable alternative to diesel fuel (G.R. Kannan et al. 2011). Efficient energy development with less environmental pollution and improved engine performance can be achieved with optimized parameters like water emulsion with biodiesel, injection timing and fuel injection angle (Suresh Vellaiyan \& K.S. Amirthagadeswaran. 2016). Value added by products from biodiesel production like glycerin and generated residue will enhance the market value for biodiesel production (Emerson Léo et al. 2014). The use of dimethoxymethane (DMM) blends in diesel engine shortens the ignition delay, combustion duration, smoother in combustion profile and no knocking is observed (B. Deepanraj et al. 2016). For increasing engine speed operated with DME and ULSD fuels the NOx emissions decreased (Joonho Jeon et al. 2014). As the equivalence ratio increases the ignition delay increases for all fuel blends (Vu Nguyen Hoang et al. 2015). Vegetable oils are eco-friendlily, renewable and easily produce in rural areas hence they will be the promising alternative for diesel engines (Srivasata, A. and Prasad, R. 2000; A. Forhad et al. 2009). The mass biodiesel production using domestic waste cooking oil and restaurant waste cooking oil is a feasible solution for faster petro diesel depletion and environmental degradation (Heidi Lai-ling Li and Peter Hoi-fu Yu. 2015). The in cylinder peak pressure increased and ignition delay decreased when jatropha biodiesel share in diesel blends where as NOx and $\mathrm{CO} 2$ increased and PM and smoke are reduced (Gaurav Paul et al. 2014). Sunflower oil biodiesel exhibits the better properties and they are within ASTM D 6751 and the EN 14214 standards (B. B. Uzun et al. 2014).

More than $95 \%$ of biodiesel production sources are from edible oils, e.g., coconut oil, corn oil, hemp oil, sunflower oil, canola oil, palm oil, soybean oil, rice bran oil, fish oil, macadamia oil, nut oil, peanut oil, etc $(\mathrm{N}$. Sh. El-Gendy et al. 2014). The different biodiesel and its blends derived from vegetable oil and animal fat oil namely rice brain oil, sunflower oil, coconut oil, tobacco seed oil, rubber seed oil, waste cooking oil, soyabean oil, sesame oil and water hyacinth oil can be successfully use in the internal combustion engines with better performance in turn lower emissions like HC, CO and smoke (Mohit Vasudeva et al. 2016; Ferial A et al. 2003; A.M. Liaquat et al. 2013; N.Usta . 2005; A.S. Ramadhas et al. 2005; Osmano Souza Valente et al 2011; Roberto G et al. 2007; S-ehmus Altuna et al. 2008; Akhilesh Kumar et al. 2015).

The biodiesel can be produced by using dairy waste scum with optimum transestrification parameters. Dairy scum biodiesel is suitable as an alternative fuel to the conventional diesel with recommended ASTM 6751 standard properties. The production of biodiesel from dairy waste scum will reduce the production cost and disposal problem (P. Sivakumar et al. 2011). The response surface methodology (RSM) with central composite design can be used to determine the optimum conditions for scum oil biodiesel production and the characterization of scum oil biodiesel is made using Fourier Transform Infrared Spectroscopy (FTIR) Biodiesel properties like density, kinematic viscosity, calorific value, flash point, pour point, copper corrosion, cloud point, carbon residue and ash content are determined and the scum biodiesel produced with optimum conditions are within ASTM standards (K.V Yatish et al. 2016). The dairy scum biodiesel can be produced using dairy washed milk scum (DWMS) which is a dairy waste but biodiesel is poor in cold flow where it is improved with use of acetoacetate (EAA) and ethyl levulinate (EL). The properties of DWMS biodiesel like kinematic viscosity, acid value, and oxidation stability with different EAA and EL added samples $(0,5,10,15$ and $20 \%$ by volume $)$ are within limits of ASTM D6751standard. Hence DWMS biodiesel is promising alternative fuel for compression ignition engine whereas addition of EAA and EL with scum 
biodiesel will improve the cold flow for biodiesel (H.V. Srikanth et al. 2017).

Improvement of engine performance with biodiesel operation can be achieved with slight modification in fuel and engine. In this regard various researchers studied the engine performance with slight modifications in fuel and engine. The experimental results revealed that addition of additive in karanja oil biodiesel will reduce the ignition delay, HRR, CO, smoke and NOx (Pinkesh R et al. 2016). From the experimental study it observed the Rice Husk nanoparticles added with pongamia biodiesel improve the BTE and emissions like CO, HC and NOx (K. Vinukumar et al. 2017). Nanoparticles and their proper distribution in biodiesel reduce the $\mathrm{CO}, \mathrm{HC}$, smoke opacity and Nox emissions (S. Karthikeyan \& A. Prathima. 2016; C. Ananda Srinivasan et al. 2017; S. Padmanabhan et al. 2017). Higher injection pressure improves atomization and mixing leading to better combustion hence more heat is released (Sukumar Puhan et al. 2009). The CO2, CO, HC and NOx emissions are lower for Jatropha and Pongamia biodiesel blends compare to diesel (H. Yogish et al.2013). At higher injection pressure waste cooking palm oil biodiesel shows the improved performance and emission parameters (G. R. Kannan et al. 2013). Combustion duration of Calophyllum inophyllum oil at higher CR is more, while the ignition delay period is lower than that of petroleum diesel (Swarup Kumar Nayak et al. 2015). Higher compression ratio (CR) induces high cylinder temperature which enhances vaporization and thereby better performance but greater in nitrogen oxides (G. Antony Miraculas, et al. 2016). The experimental result proves that the increase in compression ratio decreases the $\mathrm{HC}$, CO emission for esterified tamanu oil used in the diesel engine (T. Mohanraj and K. Murugu Mohan Kumar. 2013). The engine performance and emissions can be improved by varying fuel injection strategies (Balaji Mohan et al 2015). Increasing nozzle axial location more NOx and less CO emissions are resulted at higher speed (Amin Maghbouli et al. 2015). Combined increase of compression ratio and injection timing improves the BTE, BSFC and emissions levels (Senthil Ramalingam et al. 2015). The engine performance and emissions can be optimized by advancing fuel injection timing with diesel-DMM blends operation in engine (Ruijun Zhu et al. 2013). The retarded injection timing resulted in increased BTE and decreased CO, HC and NOx compare standard injection timing with use of waste plastic oil (M. Mani, G. Nagarajan. 2009; S. Prasanna et al. 2015). The pre-injection strategies cause negligible thermal losses and exergetic efficiencies (Joonho Jeon, Sungwook Park. 2015). NOx emissions are increased with advanced injection timing (S. Prasanna et al. 2015). Homogeneous combustion caused by the pilot injection hence helps to suppresses soot formation (Joonho Jeon, Sungwook Park. 2015). Start of injection which has strong atomization and mixture formation process and EGR (exhaust gas recirculation) application in engine significantly reduces the engine emissions for a given load and speed (Suresh K et al. 2016). The HC and CO emissions are higher for runs with optimized parameters like CR, injection pressure and EGR (exhaust gas recirculation) application, but these can be easily reduced by using a catalytic converter (P. Brijesh et al. 2015). The improvement in emission and performance of diesel engine with biodiesel operation can be also achieved with suitable combustion chamber geometry (M. N Channappagoudra et al. 2013).

The high viscosity of biodiesel for long term run causes some problems in atomization of injector systems, deposition on injector, gum formation and ring sticking. Different innovative methods like preheating, variation of injection pressure, injection timing, compression ratio, nao additive uses, catalytic convertor, particulate filters and EGR application can be developed to solve high viscosity and low volatility problems of biodiesel. Exhaustive literature survey encouraged to study the engine performance by considering slight modifications in the engine with biodiesel operation. In this regard objective of the research work is formed to study the effect of injection timing on performance, combustion and emission characteristics of diesel engine operated with DSOMEB20.

\section{Materials and methods}

\subsection{Biodiesel production}

Turbid white color and semisolid dairy waste scum (Fig.1) is collected from diary effluent treatment plant in fresh condition and heated it up to $50-60^{\circ} \mathrm{C}$ to melt it into liquid and allowed to settle down to remove lower aqueous phase. Top oil layer is separated, centrifuged and filtered to remove unwanted suspended wastes.

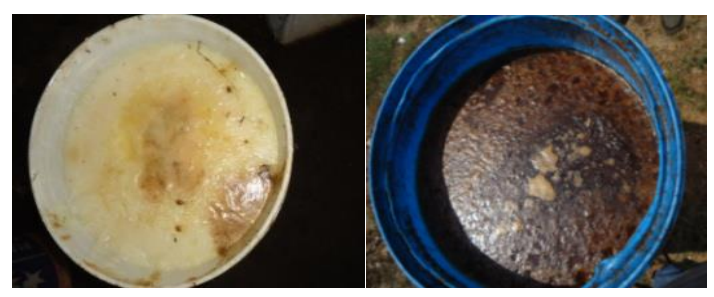

Fig.1 Dairy scum and scum oil

Schematic diagram of biodiesel production plant is shown in Fig.2. Equipments and instruments used for transesterification are stirrer, filter, electrical heater, stainless steel reactor, biodiesel and glycerin tanks, control valves; used raw materials are diary scum oil, methanol and potassium hydroxide.

The separated scum oil is processed under transesterification method where oil is mixed with methanol and potassium hydroxide $(\mathrm{KOH})$ catalyst in stainless steel reactor with stirrer for 2 hours at $60^{\circ} \mathrm{C}$ and then it is kept for 12 hour to get biodiesel and 
glycerin. Then bottom settled glycerin is taken off in glycerin tank. Three times produced crude biodiesel (methyl ester) is washed with distilled water to remove acids, soaps and residual catalyst. At the end, transesterified biodiesel is heated to $110^{\circ} \mathrm{C}$ to remove the dissolved water particles which are present in the biodiesel. The procedure is repeated until getting clear biodiesel.

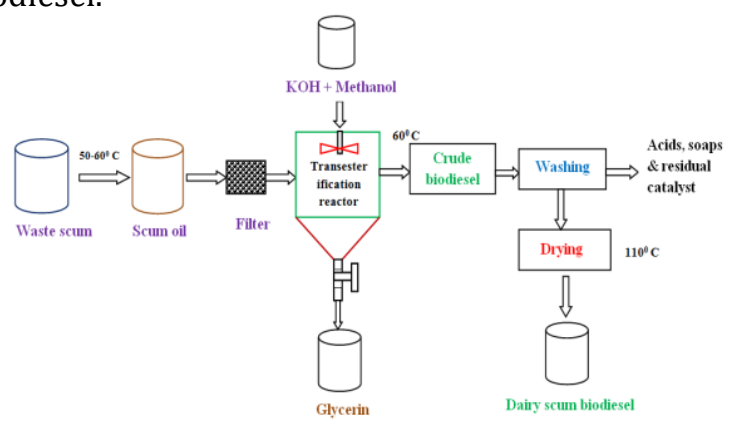

Fig.2 Process of biodiesel production

\subsection{Biodiesel properties}

Right fuel with right proportion and slight engine modification may helps in getting better usage of fuel in engine. In this regard transesterified dairy scum biodiesel is considered for experimental investigations. The properties of DSOME and its blends such as viscosity, calorific value are, density and flash point and fire point are determined as per ASTM- 6751 standards. Table1 shows properties of biodiesel.

The density of biodiesel is measured using a hydrometer at a temperature of $30{ }^{\circ} \mathrm{C}$. The flash points of the samples are measured by using Pensky-Martens closed-cup apparatus in $40-250{ }^{\circ} \mathrm{C}$ temperature range. The calorific value of biodiesel and its blends is measured in a bomb calorimeter. The Redwood viscometer is used to measure viscosity of the biodiesel at a $40^{\circ} \mathrm{C}$ temperature.

Table 1 Properties of diesel and biodiesel blends

\begin{tabular}{|c|c|c|c|c|c|c|}
\hline Properties & Methods IS 1448 & Diesel & DSOME-B10 & DSOME-B20 & DSOME-B30 & DSOME-B100 \\
\hline Density $\left(\mathrm{kg} / \mathrm{m}^{3}\right)$ & $\mathrm{P}: 16$ & 830 & 833 & 840 & 844 & 870 \\
\hline Viscosity at $40^{\circ} \mathrm{C}(\mathrm{cSt})$ & $\mathrm{P}: 25$ & 2.9 & 2.94 & 2.98 & 3.15 & 4.36 \\
\hline Calorific value $(\mathrm{kJ} / \mathrm{kg})$ & $\mathrm{P}: 6$ & 43000 & 42935 & 40890 & 40012 & 38012 \\
\hline Flash Point $\left({ }^{0} \mathrm{C}\right)$ & $\mathrm{P}: 69$ & 50 & 55 & 58 & 62 & 130 \\
\hline Fire point $\left({ }^{\circ} \mathrm{C}\right)$ & $\mathrm{P}: 69$ & 60 & 66 & 68 & 75 & 142 \\
\hline
\end{tabular}

\subsection{Experimental setup}

Kirloskar Company made single cylinder, 4 stroke, diesel engine of $3.5 \mathrm{~kW}$ (TV1) as shown in (Fig.3 \& Fig.4) is used to conduct the experiments. The standard engine specifications are given in Table 2. Instruments used for the defined work are diesel engine-test rig, ECU, Exhaust gas analyzer, burette and stopwatch, digital manometer, Chromel Alumel (K-Type) thermocouples. "Engine soft LV" software is applied for online combustion analysis. Piezosensor and crank angle sensor which measures the combustion pressure and the corresponding crank angle respectively, are mounted into the engine head and flywheel. The test engine is directly coupled to an electric dynamometer to digital control of loading and a piezoelectric pressure sensor is flush mounted on the engine's cylinder head for capturing the in-cylinder pressure data. The engine operates at a constant speed of 1500 rpm. Temperature sensors are provided for the measurement water jacket temperature, calorimeter water, and calorimeter exhaust gas inlet and outlet temperature. To prevent overheating of the dynamometer, water is circulated through the casing using a pump. To obtain the baseline parameters, the engine is first operated on pure diesel oil. Airrex Automotive Emission Analyzer HG-540 is used to measure the exhaust emissions such as Hydrocarbons (HC), Carbon Monoxide (CO) and Oxides of Nitrogen (NOx).

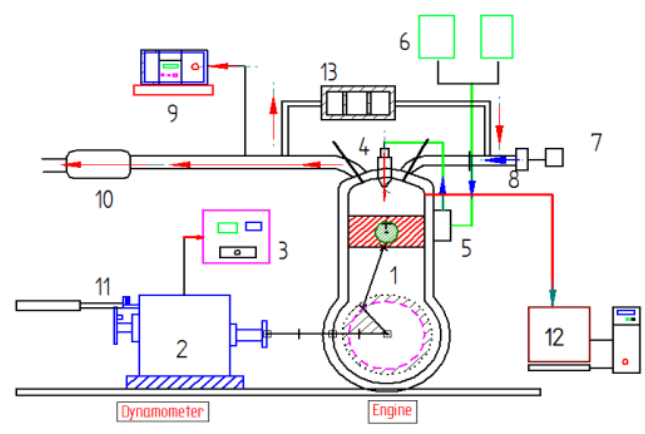

1. Kirloskar TV1 engine, 2. Eddy Current Dynamometer, 3. Control Panel, 4 Fuel Injector, 5.Fuel pump, 6.Fuel tank, 7. Air filter, 8.air stabilizing tank 9. Exhaust gas analyzers, 10. Exhaust gas silencer, 11 Crank encoder, 12. Data acquisition system

Fig.3. Schematic diagram of experimental set up.

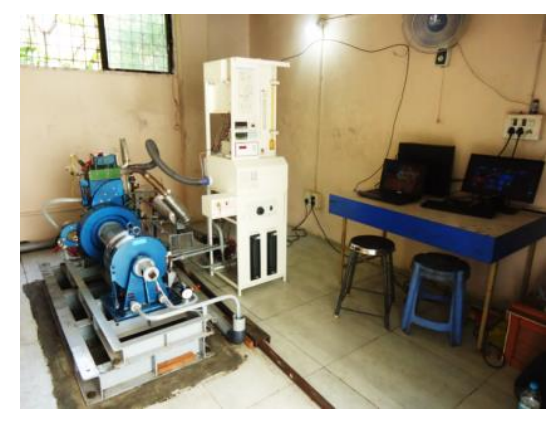

Fig.4. Photographic view of experimental test rig 
Table 2 Specifications of the engine

\begin{tabular}{|c|c|}
\hline Parameters & Specifications \\
\hline Machine suppliers & $\begin{array}{c}\text { Apex Innovations Pvt. Ltd } \\
\text { Sangli, India. }\end{array}$ \\
\hline Type & TV1 (Kirloskar made) \\
\hline Cubic capacity & $661 \mathrm{cc}$ \\
\hline Bore and stroke length & $210 \mathrm{bar}$ \\
\hline Injector opening pressure & $3.5 \mathrm{~kW}$ at $1500 \mathrm{rpm}$ \\
\hline Rated power & $23^{\circ} \mathrm{bTDC}$ (diesel) \\
\hline Injection timing & Single cylinder $/$ four stroke \\
\hline No. of cylinder/stroke & 17.5 \\
\hline Cooling & Eddy current \\
\hline Compression ratio & Engine soft \\
\hline Dynamometer &
\end{tabular}

\subsection{Experimental investigations}

The tests are conducted on a diesel engine for pure diesel and DSOME blends at constant speed. The experiments are conducted from zero load to maximum load conditions in steps of $0,20,40,60,80$ and $100 \%$ load. Different biodiesel blends are prepared and studied their effect on engine performance and aimed to optimize the best blend ratio at first phase and optimized blend is carried to the second phase of work. In the second phase of work slight engine modification is made in the fuel injection timing using provided arrangement (as shown in Fig.5) in step of 4 degrees such as 20,23, 26 and 29.deg.bTDC and aimed to compare the results with standard diesel (23.deg.bTDC) engine with optimized DSOME blend operation.

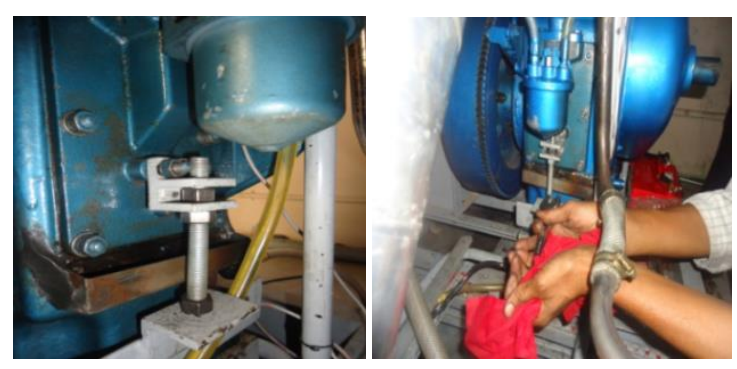

Fig.5. Injection time setting

In this present work engine performance, combustion and emission analysis is made using established engine test set up Engine performance parameters like brake thermal efficiency, brake specific fuel consumption. Combustion parameters like, cylinder pressure, rate of pressure rise, net heat release rate and cumulative heat release rate are recorded.

\section{Results and discussion}

The time of fuel injection during compression stroke when the piston approaches the top dead centre affects the combustion process. Basic performance and emission characteristics of a single cylinder diesel engine fuelled with diesel, and DSOME blends are studied and optimized the best blend, then optimized blend carried further to study the effect of injection timing on engine performance. The standard engine parameters like engine speed $1500 \mathrm{rpm}, 3$ hole nozzle , compression ratio of 17.5 and injection pressure of 210 bar for diesel and 230 bar for biodiesel is kept constant for entire study. Experiments are carried out for different loads and different ITs in step of 3 degree such as 20.deg.bTDC, 23.deg.bTDC 26.deg.bTDC and 29.deg.bTDC. HC, CO, and NOx emissions are recorded and compared with neat diesel. Based on the experimental results, optimum blend ratio and injection timing is determined for DSOME fuel.

\subsection{Phase-1: Effect of DSOME blends on diesel performance and emission characteristics}

In this first phase of work experiments are carried to optimize the best blend ratio in DSOME-B10, DSOMEB20, DSOME-B30 and DSOME-B100 and optimized blend among above is carried for further investigations.

\subsubsection{Brake thermal efficiency}

Fig. 6 shows the variation of BTE with brake power for Diesel and different DSOME blends. From the study it is observed that BTE for dairy scum biodiesel engine operation is lower than neat diesel $(31.32 \%)$ operation over the entire load range it may attributed to lower heating value, higher density, lower adiabatic flame temperature and greater viscosity. And also increase in biodiesel percentage with diesel will reduce the BTE because of reduced calorific value. From results it is noticed that DSOME-B10 and DSOME-B20 blends have BTE values of $30.42 \%$ and $29.93 \%$ respectively and they are close to each other. However saving of $10 \%$ petroleum diesel is not a good savings against petroleum diesel even it has higher BTE. The other blends DSOME-B30 (29.04\%) and DSOME-B100 (28.37\%) have lower BTE than DSOME-B10 and DSOME-B20. Hence DSOME-B20 is considered as optimum blend among others.

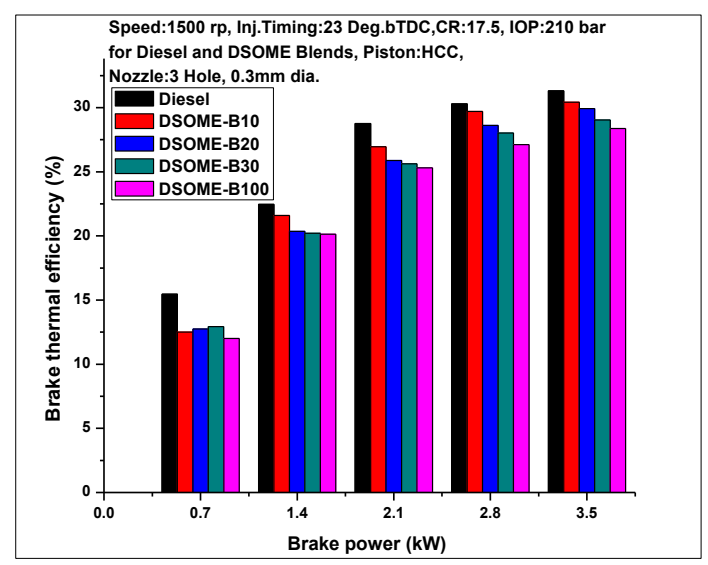

Fig.6. Variation of brake thermal efficiency with brake power 


\subsubsection{Brake specific fuel consumption}

Fig.7 depicts the variations of BSFC with brake power for different dairy scum biodiesel blends. Graph shows that the BSFC increases with the increase in percentage of biodiesel in the in diesel. This may be attributed to the lower heating values of biodiesel and higher viscosity. The BSFC for diesel is lower among all blends the reason may higher calorific value and lower viscosity and specific gravity of the diesel fuel leads complete combustion. the BSFC for DSOME-B30 and DSOME-B100 are higher when compared to DSOMEB10 and DSOME-B20 it may due to lower calorific value, higher density and viscosity leads improper mixing of air and fuel hence cause incomplete combustion. From experimental investigations the BSFC results for Diesel, DSOME-B10, DSOME-B20, DSOME-B30 and DSOME-B100 are found to be 0.29 , $0.304,0.320,0.341$, and $0.352 \mathrm{~kg} / \mathrm{kW} . \mathrm{hr}$ respectively at full load. The BSFC of DSOME-B20 (0.320 kg/kW.hr) is nearer to DSOME-B10 $(0.304 \mathrm{~kg} / \mathrm{kW} . \mathrm{hr})$ when compared to other blends.

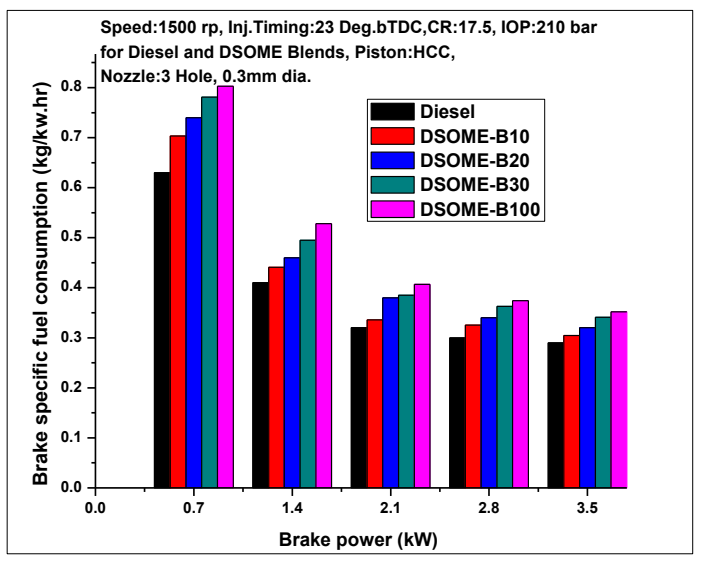

Fig.7. Variation of brake specific fuel consumption with brake power

\subsubsection{Hydrocarbons emission}

Fig.8 shows the variation of hydrocarbon emission with brake power for diesel and dairy scum biodiesel blends. As the speed and load varies the concentration of HC in diesel engine varies. The HC emission levels are lower for dairy scum biodiesel operation compared to petroleum diesel operation. This might be due to increased gas temperature, higher cetane number more oxygen content in biodiesel causes the complete combustion. At maximum load the DSOME-B100 and DSOME-B30 shown the lower HC emissions of $36 \mathrm{ppm}$ and 39 ppm among other blends it could be attributed to more inherent oxygen presence in the higher concentration of biodiesel tends improved combustion. From the experimental results it is observed that DSOME-B10 has higher HC emissions of 43 ppm than DSOME-B20 HC emission of 40 ppm at maximum load.

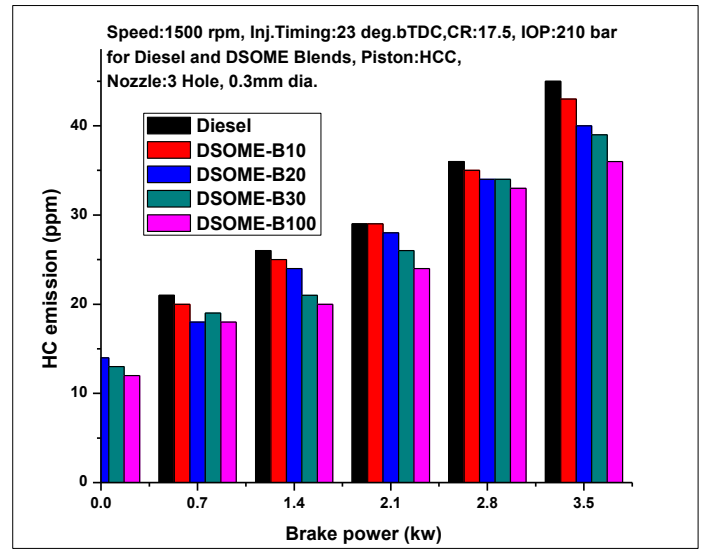

Fig.8. Variation of HC emission with brake power

\subsubsection{Carbon monoxide emission}

The comparison of $\mathrm{CO}$ emissions with brake power for neat diesel and DSOME blends are represented in Fig.9. CO emission of biodiesel and their respective blends are lower than the petro diesel as they have more oxygen content. These lower CO emissions of DSOME blends may be due to their more complete oxidation and improved combustion as compared to diesel. It can be seen from graph that the $\mathrm{CO}$ emission initially decreased with increasing load because of at no load temperature of cylinder might be too low and later increased sharply up to maximum load. At $100 \%$ load CO emissions for Diesel, DSOME-B10, DSOME-B20, DSOME-B30 and DSOME-B100 are 0.089, 0.081, 0.076, 0.069 , and $0.062 \%$ respectively. The experiment clears that CO emission decrease with increased biodiesel blend concentration. The DSOME-B100 and DSOMEB30 have lower CO emissions followed by DSOME-B20. From the above results it's clear that DSOME-B20 blend has lesser $\mathrm{CO}$ of $0.076 \%$ when compared to DSOME-B10 of $0.081 \%$.

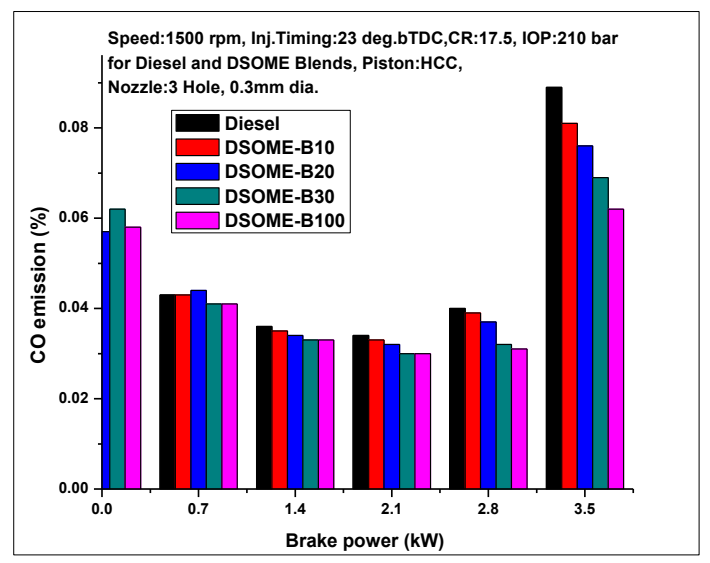

Fig.9.Variation of CO emission with brake power

\subsubsection{Oxides of nitrogen emission}

Fig.10 shows the variations of NOx emissions with brake power for standard Diesel and DSOME blends. NOx emission is found to be higher for DSOME blends 
compared to diesel over the entire load range. It may attribute to be higher heat release rate and temperature during premixed combustion phase as biodiesel blends have more oxygen content compare to diesel leads better combustion. The NOx level is higher for DSOME-100 compared to DSOME-B10, DSOME-B20 and DSOME-B30 blends. The reason may be better combustion rate due to more homogeneous air-fuel mixing tends to larger part of combustion at just before top dead center. From the experimental results, it could be noted that the DSOME-B100 gives highest nitrogen oxides among other blends. At maximum load condition, NOx emissions for Diesel, DSOME-B10, DSOME-B20, DSOME-B30 and DSOME-B100 are found to be $961,976,1006,1021,1085$ ppm respectively.

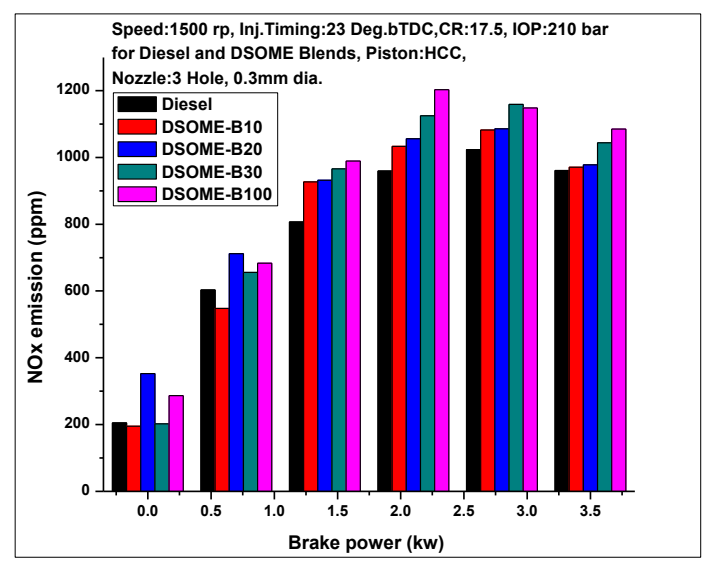

Fig.10.Variation of NOx emission with brake power

3.2 Phase-2: Effect of injection timing on diesel performance, combustion and emission characteristics

\subsubsection{Brake thermal efficiency}

Variation of BTE with brake power for different injection timings are represented in Fig.11. The BTE increases with the increase in engine loads. Based on brake thermal efficiency fuel injection timing of 23.deg.bTDC (engine manufacturer) is the best for diesel. For DSOME-B20, BTE decreased when compared with diesel fuel, at 23.deg.bTDC it might be attributed to lower energy content, higher viscosity of the fuel and higher fuel consumption for the same power output. The combustion is slow with DSOMEB20 because of its high viscosity which leads to a poor spray and mixture with air. This is because starting the combustion earlier compensates the effect of slow burning. The BTE increased when the injection timing is advanced whereas ignition delay period is increased hence more time is available in the combustion chamber for physical processes like, fuel -air mixing, heating and evaporation process it helps by providing ready air-fuel mixer for combustion process. This results in a higher rate of heat release, causing higher cylinder pressures and temperatures leads to higher BTE. Whereas by retarding the IT from 23.deg.bTDC to 20.deg.bTDC will reduce the ignition delay hence improper mixing of fuel and air which is associated to shorter delay leads lower BTE and heat release rate. From experimental study it is revealed that BTE values for Diesel-23.deg.bTDC, 20.deg.bTDC, 23.deg.bTDC 26.deg.bTDC and 29.deg.bTDC are 31.32, 28.21, 30.55 31.03 and $29.15 \%$ respectively for the DSOME-B20 operation at full load. For DSOME-B20, 26.deg.bTDC is considered as the optimum injection timing as it has BTE of $31.03 \%$ near to Diesel BTE of $31.32 \%$. It is attributed to combination of low mass flow rate and volatility (Senthil Ramalingam et al. 2015). Based on BTE values 26.deg. bTDC IT is the optimum for DSOMEB20 operation.

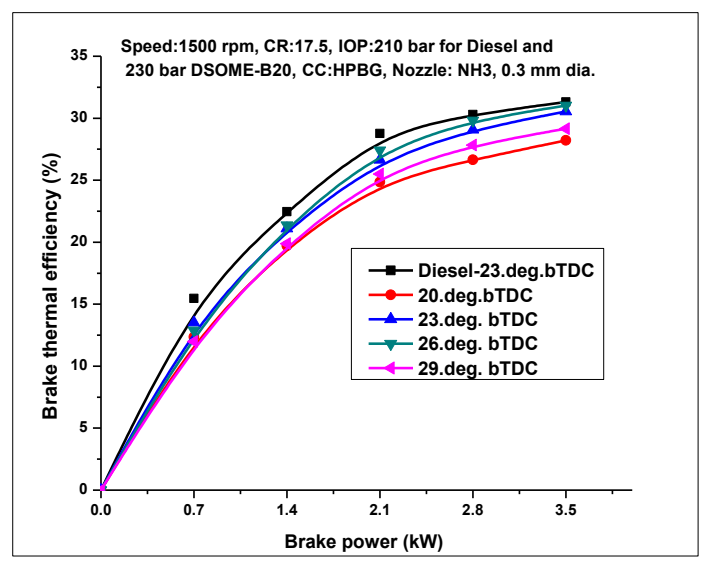

Fig.11. Variation of brake thermal efficiency with brake power

\subsubsection{Brake specific fuel consumption}

Fig.12 shows the variation of BSFC with brake power for different ITs.

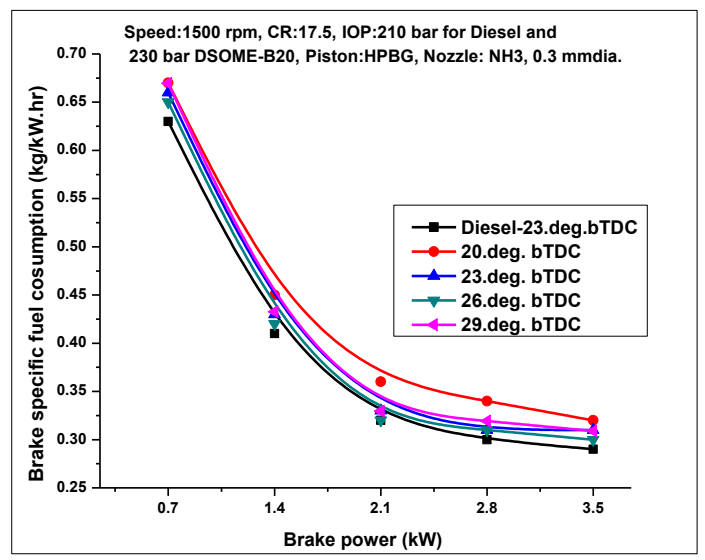

Fig.12. Variation of brake specific fuel consumption with brake power

The DSOME-B20 results are compared with neat diesel at different loads. For both the fuels as load increased, the BSFC gradually decreased. It is observed from the figure that the BSFC is higher with DSOME-B20 for all injection timings and loads when compared to diesel. This trend is attributed to the lower calorific value of DSOME-B20 than that of the diesel hence more quantity of biodiesel introduced into the combustion chamber to produce same output power as of diesel. 
When IT for DSOME-B20 is advanced from 23.deg.bTDC to 26.deg.bTDC there is more time available for mixture preparation leads improvement in premixed combustion phase (Venkanna et al. 2011). Therefore based on BSFC values advanced 26.deg.bTDC IT gave the lower fuel consumption of $0.300 \mathrm{~kg} / \mathrm{kW} . \mathrm{h}$ than standard 23.deg.bTDC IT of $0.310 \mathrm{~kg} / \mathrm{kW} . \mathrm{h}$. The experimental results revealed that brake specific fuel consumption at maximum load for Diesel-23.deg.bTDC, 20.deg.bTDC, 23.deg.bTDC, 26.deg.bTDC and 29.deg.bTDC are $0.290,0.320,0.310,0.300$ and 0.309 $\mathrm{kg} / \mathrm{kW} . \mathrm{h}$ respectively.

\subsubsection{Hydrocarbons emission}

Fig.13 depicts the effect of IT on diesel engine HC emissions operated with diesel, and DSOME-B20. HC emission in diesel engines is caused due to lean mixture during delay period and under mixing of fuel leaving from injector nozzle at lower velocity. The general trend of decreased HC emission for DSOMEB20 is observed as compared to diesel for all three ITs. This may be attributed to increased combustion efficiency with DSOME-B20 as the preparation of airfuel mixture rate is improved leads to improved premixed combustion phase. From the results it is noticed that HC levels are decreased with higher IT of 26.deg.bTDC with DSOME-B20 operation. This attributed to improved oxidation and proper mixing of fuel and air thus cause complete combustion. The HC emission results for Diesel-23.deg. bTDC, 20.deg.bTDC, 23.deg.bTDC, 26.deg. bTDC and 29.deg.bTDC are found to be $45,46,38,37$ and $41 \mathrm{ppm}$ at maximum load. From the experimental results it's clear that HC emissions are lower for 26.deg.bTDC IT when compared to standard diesel 23.deg.bTDC.

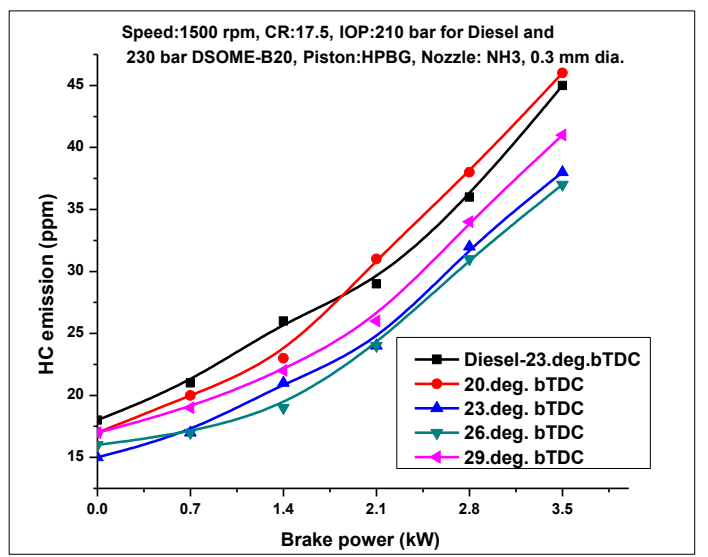

Fig.13. Variation of HC emission with brake power

\subsubsection{Carbon monoxide emission}

Fig.14 represents the variation of $\mathrm{CO}$ emissions with brake power for Diesel and DSOME-B20 with different injection timings. With DSOME-B20, CO is the least at all loads for 26.deg.bTDC IT compared to other ITs. This is due to improved combustion (increase in cylinder pressure and temperature), BTE and conversion of $\mathrm{CO}$ into $\mathrm{CO}_{2}$ by taking additional oxygen molecules which are present in DSOME-B20 and use of over leaner fuel air mixtures as compared to other ITs (Venkanna et al. 2011). As the injection timing is advanced from 23.deg.bTDC to 26.deg.bTDC CO emission reduced which is attributed to increase in premixed heat release rate leads better combustion efficiency. The CO emission reduced from 0.071 to $0.067 \%$ when IT is increased to 26.deg.bTDC. The CO emission values at $100 \%$ load for Diesel-23.deg.bTDC 20.deg.bTDC, 23.deg.bTDC, 26.deg. bTDC and 29.deg bTDC are $0.089,0.1028,0.071,0.067$ and $0.069 \%$ respectively. The 26.deg.bTDC IT has lowest CO emission of $0.067 \%$ when compared to standard diesel 23.deg.bTDC of $0.089 \%$.

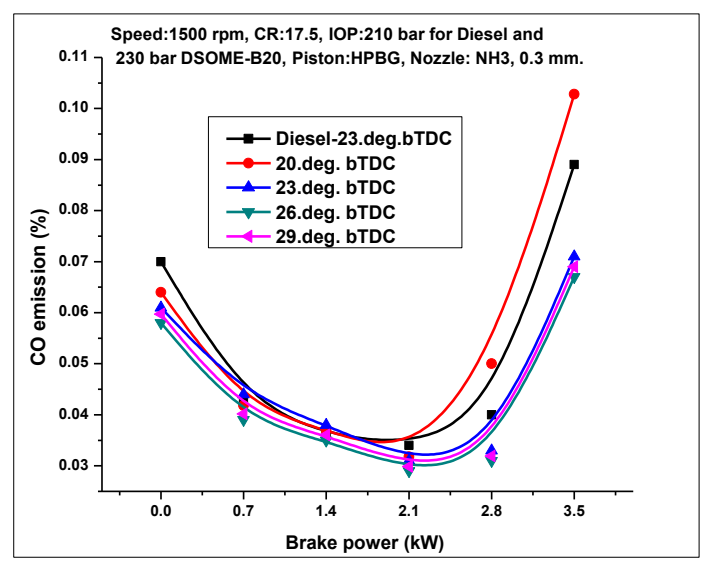

Fig.14. Variation of CO emission with brake power

\subsubsection{Oxides of nitrogen emission}

Fig.15 depicts the variation of nitrogen oxides with brake power for different injection timings.

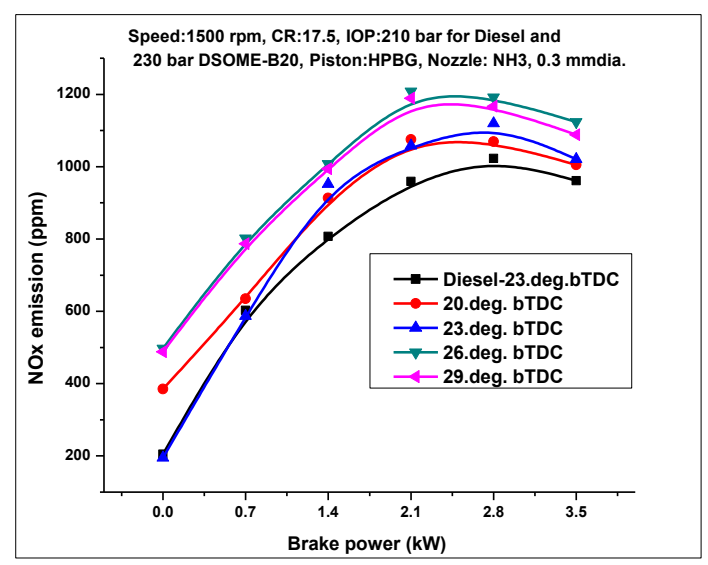

Fig.15. Variation of NOx emission with brake power

NOx emissions increased with all load, Whereas With increasing load, fuel consumption rate increases and hence more heat is released during combustion since combustion chamber temperature increases which leads increase in NOx emission. The NOx emission level is increased as the IT is advanced. This is due to the dominance of the premixed combustion phase leading 
to higher peak pressure and higher cylinder temperature (Venkanna et al. 2010). The NOx is increased from $1021 \mathrm{ppm}$ to 1124 when IT is advanced 23.deg.bTDC to 26.deg.bTDC with DSOME-B20 operation. Which attributed to more time availability for air to mix with fuel hence improves the oxidation and combustion. The NOx emissions values at full load for Diesel-23.deg. bTDC, 20.deg.bTDC, 23.deg.bTDC, 26.deg. bTDC and 29.deg. bTDC are found to be 961, $1005,1021,1124$ and 1088 ppm respectively.

\subsubsection{Cylinder pressure}

Variation of cylinder pressure with crank angle at maximum load fueled with Diesel and DSOME-B20 at different ITs are shown in Fig.16. DSOME-B20 had less trace of pressure waves and also the variation of gas pressure is smoother at full load when the injection time is advanced since engine noise is normal. The cylinder pressure is highest with Diesel of 53.63 bar at 23.deg.bTDC followed by DSOME-B20 of 52.29 bar at 26.deg.bTDC IT. By advancing the injection timing from 23.deg.bTDC to 26.deg.bTDC ignition delay period increases and smoother in engine operation. From graph it is observed that effect of advanced IT of 26.deg.bTDC operation with DSOME-B20 on engine performance is highly prominent. From the experimental study cylinder pressure values for Diesel23.deg.bTDC, 20.deg.bTDC, 23.deg.bTDC, 26.deg. bTDC and 29.deg. bTDC are 53.63, 50.2, 50.81, 52.29 and 50.7213 bar respectively at maximum load. Among above peak pressures of different ITs the IT 26.deg.bTDC has highest cylinder pressure of 52.29 bar. It might due to better mixing of air molecules with fuel leads better oxidation and combustion hence releases more chemical and heat energy hence cause the more cylinder pressure.

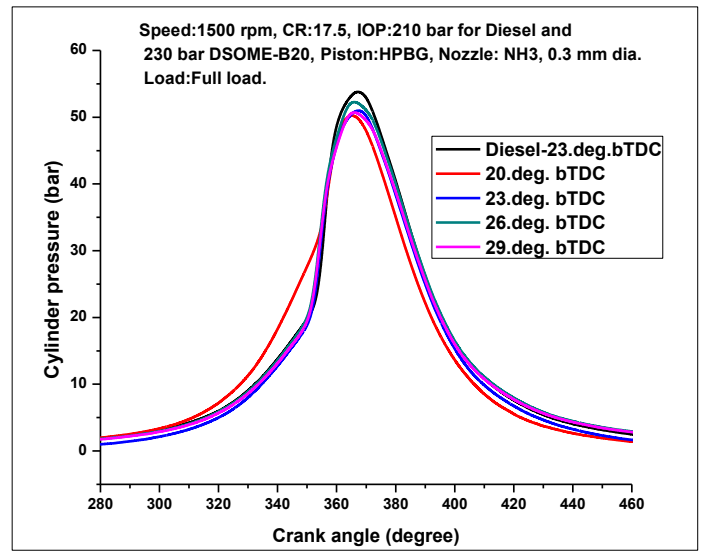

Fig.16. Variation of cylinder pressure with crank angle at full load

\subsubsection{Heat release rate}

The variation of heat release rates with Diesel and DSOME-B20 for different ITs at full load are represented in Fig.17. Initially a slight negative heat release rate is observed during ignition delay period which is due to cooling effect of vaporization of the DSOME-B20 blend and loss of heat from cylinder walls (John B.LHeywood. 1988) and later on it turns into positive when combustion starts. The heat release rate for DSOME-B20 at 26.deg.bTDC is lower than diesel at 23.deg.bTDC. It might be with the lower calorific value and poor atomization of DSOOME-B20 as it causes poor preparation of fuel-air mixture during delay period. In operation with DSOME-B20 the improved combustion efficiencies are achieved by advancing injection timing from 23.deg.bTDC to 26.deg.bTDC hence ignition delay increased which is due to earlier injection of fuel in compression stroke hence more time availabile for mixing of air and fuel, vaporization and pre combustion reaction in the combustion chamber Venkanna $\mathrm{K}$ et al. 2010). Whereas by retarding the IT from 23.deg.bTDC to 19.deg.bTDC will reduce the ignition delay hence decrease in heat release rate and cylinder temperature which may due to improper mixing of fuel and air. The experimental values of heat release rate for Diesel23.deg.bTDC, 20.deg.bTDC, 23.deg.bTDC, 26.deg. bTDC and 29.deg. bTDC are 65.43, 53.64, 62.22, 63.35 and $61.45 \mathrm{~J} / \mathrm{crank}$ angle respectively at full load. Among above heat release rates the IT 26.deg.bTDC has the highest heat release rate of $63.35 \mathrm{~J} / \mathrm{crank}$ angle hence it is optimized.

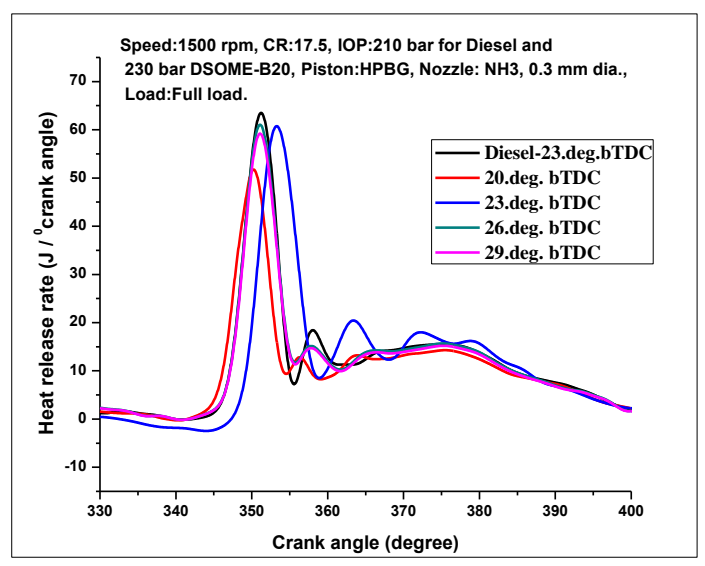

Fig.17. Variation of heat release rate with crank angle at full load

\subsubsection{Cumulative heat release rate}

Cumulative heat release with crank angle is shown in Fig.18 for the different ITs at various engine loads. It is noticed that CHRR increased towards the later part of the combustion process for 26.deg.bTDC IT. It may due to greater amount of heat is released as the more amount of fuel is available in the case of DSOME-B20 operation. The results for Diesel-23.deg.bTDC, 20.deg.bTDC, 23.deg.bTDC, 26.deg.bTDC and 29.deg.bTDC are found to be $0.80,0.752,0.79,0.806$ and $0.782 \mathrm{~J} / \mathrm{crank}$ angle. From the above experimental results it clears that the 26.deg.bTDC IT has shown highest cumulative heat release rate when compared to other ITs. This may be attributed to faster premixed combustion in the cylinder. 


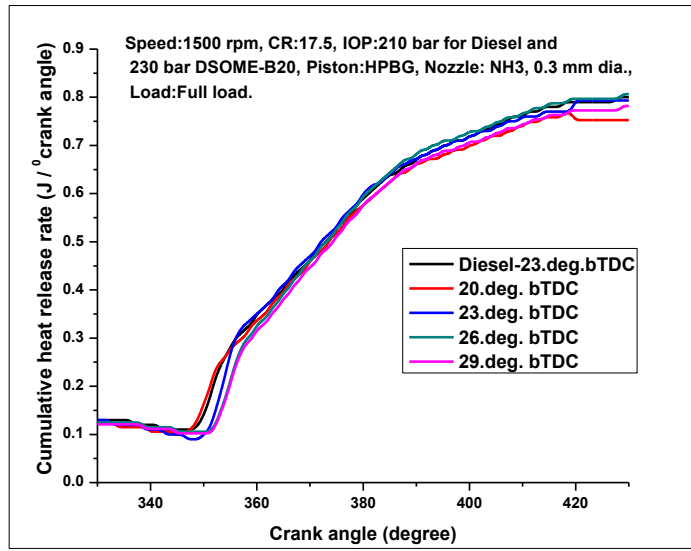

Fig.18. Variation of cumulative heat release rate with crank angle at full load

\subsubsection{Rate of pressure rise}

The comparison of rate of pressure rise with crank angle for different ITs at full load is presented in Fig. 19. When the IT is advanced the rate of pressure rise is significantly higher than that of standard IT (23.deg.bTDC). The rate of pressure rise is higher for diesel when compare to DSOME-B20 it might be due to higher viscosity, lower heating value and lower volatility of biodiesel. Because of improved combustion with DSOME-B20 at 26.deg.bTDC increased pressure rise is observed. After reaching the maximum pressure, it drops progressively to lower levels during the expansion process. The diesel has 4.6 bar/crank angle rise of pressure at 23.deg.bTDC whereas DSOME-B20 at 26.deg.bTDC has $4.3 \mathrm{bar} / \mathrm{crank}$ angle rise of pressure and which is closer to diesel. The pressure rise values for 20.deg.bTDC, 23.deg.bTDC 29.deg.bTDC are found to $3.7,4.27$ and $4.24 \mathrm{bar} / \mathrm{crank}$ angle.

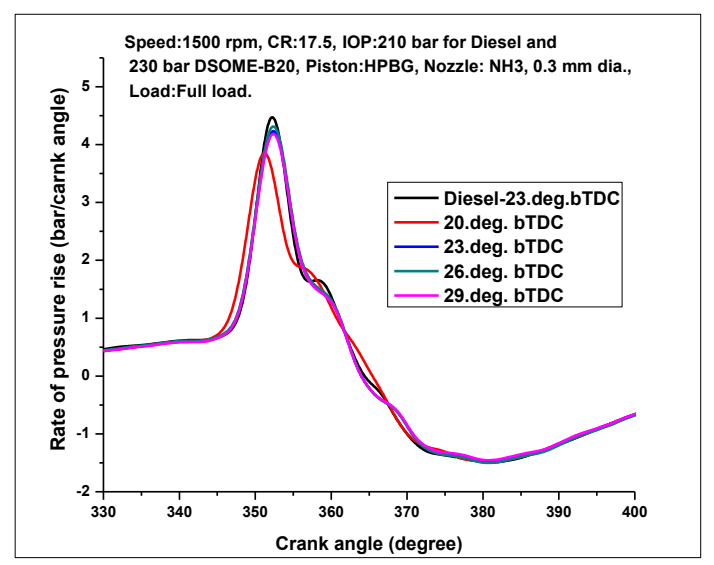

Fig.19. Variation of rater of pressure rise with crank angle at full load

\section{Conclusion}

In this experimental investigation the effect DSOME blends such as DSOME-B10, DSOME-B20, DSOME-B30 and DSOME-B100 are prepared and examined their effect on diesel engine performance and emission characteristics. In the first phase of work best blend ratio is optimized and optimized blend is considered for further investigations. In second phase of the study injection timing is varied from 20.deg.bTDC to 26.deg.bTDC in steps of 3 degrees to determine the performance, combustion and emission characteristics of diesel engine operated with optimized fuel blend. . From the experimental results the following conclusions are drawn:

1) The B20 blend is found to be best as it has improved BTE, BSFC when compared to DSOMEB30 and DSOME-B100. The DSOME-B10 blend has higher BTE than B20, however its HC, CO emissions are higher than DSOME-B20 hence DSOME-B20 is optimized and carried for further investigation.

2) When the IT is advanced from standard 23.deg.bTDC to 26.deg.bTDC the BTE is increased from $30.55 \%$ to $31.03 \%$ whereas BSFC reduced from 0.310 to $0.300 \mathrm{~kg} / \mathrm{kW}$.hr respectively at full load.

3) At maximum load HC reduced from $38 \mathrm{ppm}$ to 36 ppm and CO reduced from $0.071 \%$ to $0.067 \%$ whereas NOx is increased from $1021 \mathrm{ppm}$ to 1124 ppm when IT is advanced from 23.deg.bTDC to 26.deg.bTDC.

4) An improvement in the peak pressure and heat release is noticed with advancement of fuel injection time from 23.deg.bTDC to 26.deg.bTDC, hence ignition delay increased which is due to earlier injection of fuel in compression stroke hence more time available for mixing of air and fuel, vaporization and pre combustion reaction in the combustion chamber.

5) Too advance injection timing of 29.deg.bTDC increased the ignition delay to a larger value leading to improper air-fuel mixing, poor and sluggish combustion hence it may cause incomplete combustion therefore decreases the BTE, peak temperature, heat release rate and cylinder pressure.

On whole based performance (BTE and BSFC), combustion (Peak pressure, HRR, CHRR, and Pressure rise) and emission characteristics ( $\mathrm{HC}$ and $\mathrm{CO}$ ) of diesel engine it is concluded that the 26.deg.bTDC IT is optimum for DSOME-B20 blend.

\section{Scope for the future work}

To get maximum efficiency and least emissions of diesel engine some modifications in fuel and engines like variation of injection timing, injector opening pressure, compression ratio, and application of nano additive, water emulsion and EGR etc. will play the major role.

\section{Acknowledgement}

The authors are grateful to I \& D (Information and Demonstration on Biofuels) Centre, Biofuel Park Madenur, Hasan which is sponsored by Karnataka 
State Biofuel Development Board (KSBD), Govt. of Karnataka (India), for providing dairy scum oil biodiesel for research work. Authors also thankful to the Managing Director of Apex Innovations, Sangli (India) for providing computerized experimental setup to conduct the experiments.

\section{References}

S. Jindal , B.P. Nandwana , N.S. Rathore , V. Vashistha (2010) Experimental investigation of the effect of compression ratio and injection pressure in a direct injection diesel engine running on Jatropha methyl ester. Applied Thermal Engineering 30:442-448.

A. DEMIRBAS. Future Fuels for Internal Combustion Engines (2010) Energy Sources, Part A, 32:1273-1281.

Agarwal AK (2007) Biofuels (alcohols and biodiesel) applications as fuels for internal combustion engines. Prog Energy Combust Sci 33:233-71.

Ismet Çelikten , Emre Mutlu , Hamit Solmaz (2012) Variation of performance and emission characteristics of a diesel engine fueled with diesel, rapeseed oil and hazelnut oil methyl ester blends. Renewable Energy 48:122-126.

Yoon S H, Park SH, Lee CS (2008) Experimental investigation of the fuel properties of biodiesel and its blends at various temperatures. Energy Fuel 22:652-6.

Magı'n Lapuerta, Octavio Armas, Jose' Rodrı'guez-Ferna' ndez (2008) Effect of biodiesel fuels on diesel engine emissions. Progress in Energy and Combustion Science 34:198-223.

G.R. Kannan, K.R. Balasubramanian, S.P. Sivapirakasam and R. Anand (2011) Studies on biodiesel production and its effect on DI diesel engine performance, emission and combustion characteristics. International Journal of Ambient Energy, Vol. 32, No. 4, 179-193.

Suresh Vellaiyan , K.S. Amirthagadeswaran (2016) The role of water-in-diesel emulsion and its additives on diesel engine performance and emission levels: A retrospective review. Alexandria Engineering Journal Volume 55, Issue 3, Pages 2463-2472.

Emerson Léo Schultz, Daniela Tatiane de Souza and Mônica Caramez Triches Damaso (2014) The glycerol biorefinery: a purpose for Brazilian biodiesel production. Schultz et al. Chemical and Biological Technologies in Agriculture 1:7.

B. Deepanraj, G. Sankaranarayanan, N. Senthilkumarc and M. Pugazhvadivu (2016) Influence of dimethoxymethane addition on performance, emission and combustion characteristics of the diesel engine. International Journal Of Ambient Energy.

Joonho Jeon, Sang Il KWon, Yong Hee Park, Yunjung Oh, Sungwook Park (2014) Visualizations of combustion and fuel/air mixture formation processes in a single cylinder engine fueled with DME.Applied Energy 113:294-301.

$\mathrm{Vu}$ Nguyen Hoang, Luong Dinh Thi (2015) Experimental study of the ignition delay of diesel/ biodiesel blends using a shock tube. Biosystems Engineering 134:1-7.

Srivasata, A. and Prasad, R (2000) "Triglyceride based diesel Fuels", Renewable and sustainable Energy Reviews 4: 11111.

A. Forhad, A.R. Rowshan, M.A. Habib, M.A. Islam (2009) Production and Performance of Biodiesel as as Alternative to Diesel, ICME. TH-30.

Heidi Lai-ling Li, Peter Hoi-fu Yu (2015) Conversion of waste cooking oils into environmentally friendly biodiesel. Li and Yu SpringerPlus, 4(Suppl 2):P7.

Gaurav Paul, Ambarish Datta, Bijan Kumar Mandal (2014) An Experimental and Numerical Investigation of the
Performance, Combustion and Emission Characteristics of a Diesel Engine fueled with Jatropha Biodiesel. Energy Procedia 54:455 - 467

B. B. Uzun, M. Kiliç, E (2014) Apaydin-Varol,1 and A. E. Pütün. Optimization of Biodiesel Production and Fuel Properties of Blends. Energy Sources, Part A, 36:898-906.

N. Sh. El-Gendy, S. F. Deriase, and A. Hamdy (2014) The Optimization of Biodiesel Production from Waste Frying Corn Oil Using Snails Shells as a Catalyst. Energy Sources, Part A, 36:623-637.

Mohit Vasudeva , Sumeet Sharma, S. K. Mohapatra2 and Krishnendu Kundu (2016) Performance and exhaust emission characteristics of variable compression ratio diesel engine fuelled with esters of crude rice bran oil. Vasudeva et al. SpringerPlus 5:293.

Ferial A. Zaher, Ola A. Megahed,Omayma S. El Kinawy (2003) Esters of Sunflower Oil as an Alternative Fuel for Diesel Engines. Energy Sources, 25:1015-1022.

A.M. Liaquat, H.H. Masjuki, M.A. Kalam, I.M. Rizwanul Fattah, M.A. Hazrat, M. Varman, M. Mofijur, M. Shahabuddin (2013) Effect of coconut biodiesel blended fuels on engine performance and emission characteristics. Procedia Engineering 56:583 - 590 .

N.Usta (2005) Use of tobacco seed oil methyl ester in a turbocharged indirect injection diesel engine. Biomass and Bioenergy 28:77-86.

A.S. Ramadhas, C. Muraleedharan, S. Jayaraj (2005) Performance and emission evaluation of a diesel engine fueled with methyl esters of rubber seed oil. Renewable Energy 30:1789-1800.

Osmano Souza Valente, Vanya Márcia Duarte Pasa, Carlos Rodrigues Pereira Belchior, José Ricardo Sodré (2011) Physical-chemical properties of waste cooking oil biodiesel and castor oil biodiesel blends.Fuel 90:17001702.

Roberto G. Pereira, Cesar D. Oliveira, Jorge L. Oliveira,Paulo Cesar P. Oliveira, Carlos E. Fellows, Oscar E. Piamba (2007) Exhaust emissions and electric energy generation in a stationary engine using blends of diesel and soybean biodiesel. Renewable Energy 32: 2453-2460.

S-ehmus Altuna, Hu" samettin Bulut, Cengiz O" ner (2008) The comparison of engine performance and exhaust emission characteristics of sesame oil-diesel fuel mixture with diesel fuel in a direct injection diesel engine. Renewable Energy 33:1791-1795.

Akhilesh Kumar Choudhary H. Chelladurai1 C. Kannan (2015) Optimization of Combustion Performance of Bioethanol (Water Hyacinth) Diesel Blends on Diesel Engine Using Response Surface Methodology. Arab J Sci Eng 40:3675-3695.

P. Sivakumar , K. Anbarasu , S. Renganathan (2011) Biodiesel production by alkali catalyzed transesterification of dairy waste scum. Fuel 90:147-151.

K.V. Yatish, H.S. Lalithamba, R. Suresh, S.B. Arun, P. Vinay Kumar (2 $\left.\begin{array}{lll}2 & 1 & 6\end{array}\right)$ Optimization of scum oil biodiesel production by using response surface methodology. Process Safety and Environmental Protection 10 2:667672.

H.V. Srikanth, J. Venkatesh, Sharanappa Godiganur, S. Venkateswaran, Bhaskar Manne (2017) Bio-Based Diluents Improve Cold Flow Properties of Dairy Washed Milk-Scum Biodiesel. Renewable Energy111:168-174.

Pinkesh R. Shah , Anuradda Ganesh (2016) A comparative study on influence of fuel additives with edible and nonedible vegetable oil based on fuel characterization and engine characteristics of diesel engine. Applied Thermal Engineering 102:800-812. 
K. Vinukumar, A. Azhagurajan, S. C. Vettivel, N. Vedaraman (2017) Rice husk as nanoadditive in diesel-biodiesel fuel blends used in diesel engine. J Therm Anal Calorim,DOI 10.1007/s10973-017-6692-7.

S. Karthikeyan \& A. Prathima (2016) Emission analysis of the effect of doped nanoadditives on biofuel in a diesel engine. Energy Sources, Part A: Recovery, Utilization, and Environmental Effects,Vol. 38, NO. 24, 3702-3708.

C. Ananda Srinivasan, C. G. Saravanan, and M. Gopalakrishnan (2017) Emission reduction on ethanol-gasoline blend using cerium oxide nanoparticles as fuel additive. Particulate Science and Technology.

S. Padmanabhan, S. Ganesan, Anipeddi Masen Venkata Anvesh and Bonthu Pradeep (2017) Influence of cerium oxide additive and aloe vera biodiesel on a CI engine. International Journal of Ambient Energy.

Sukumar Puhan, R. Jegan, K. Balasubbramanian, G. Nagarajan (2009) Effect of injection pressure on performance, emission and combustion characteristics of high linolenic linseed oil methyl ester in a DI diesel engine. Renewable Energy 34:1227-1233.

H. Yogish, K. Chandarshekara, M. R. Pramod Kumar (2013) A study of performance and emission characteristics of computerized CI engine with composite biodiesel blends as fuel at various injection pressures. Heat Mass Transfer 49:1345-1355.

G. R. Kannan, K. R. Balasubramanian and R. Anand (2013) Artificial Neural Network Approach To Study The Effect Of Injection Pressure And Timing On Diesel Engine Performance Fueled With Biodiesel. International Journal of Automotive Technology, Vol. 14, No. 4, pp. 507-519.

Swarup Kumar Nayak, Santosh Kumar Nayak, Purna Chandra Mishra and Srinibas Tripathy (2015) Influence of compression ratio on combustion characteristics of a VCR engine using Calophyllum inophyllum biodiesel and diesel blends. Journal of Mechanical Science and Technology 29 (9) 4047-4052.

G. Antony Miraculas, N. Bose, R. Edwin Raj (2016) Optimization of Biofuel Blends and Compression Ratio of a Diesel Engine Fueled with Calophyllum inophyllumOil Methyl Ester. Arab J Sci Eng 41:1723-1733.

T. Mohanraj and K. Murugu Mohan Kumar. Operating Characteristics of a Variable Compression Ratio Engine Using Esterified Tamanu Oil. International Journal of Green Energy, 10: 285-301, 2013.

Balaji Mohan, Wenming Yang, Wenbin Yu, Kun Lin Tay, Siaw Kiang Chou (2015) Numerical investigation on the effects of injection rate shaping on combustion and emission characteristics of biodiesel fueled CI engine. Applied Energy XXX XXX-XXX.

Amin Maghbouli, Wenming Yang, Hui An, Jing Li, Sina Shafee (2015) Effects of injection strategies and fuel injector configuration on combustion and emission characteristics of a D.I. diesel engine fueled by bio-diesel. Renewable Energy 76:687-698.
Senthil Ramalingam, Silambarasan Rajendran, Ravichandiran Nattan (2015) Influence of injection timing and compression ratio on performance, emission and combustion characteristics of Annona methyl ester operated diesel engine. Alexandria Engineering Journal 54, 295-302.

Ruijun Zhu, Haiyan Miao, Xibin Wang, Zuohua Huang (2013) Effects of fuel constituents and injection timing on combustion and emission characteristics of a compressionignition engine fueled with diesel-DMM blends. Proceedings of the Combustion Institute 34:3013-3020.

M. Mani, G. Nagarajan (2009) Influence of injection timing on performance, emission and combustion characteristics of a DI diesel engine running on waste plastic oil. Energy 34:1617-1623

injection strategies: Effect of pre-injection timing. Applied Thermal Engineering 53:21-30.

Joonsik Hwang, Donghui Qi, Yongjin Jung, Choongsik Bae (2014) Effect of injection parameters on the combustion and emission characteristics in a common-rail direct injection diesel engine fueled with waste cooking oil biodiesel. renewable Energy 63:9-17.

S. Prasanna Raj Yadav , C.G. Saravanan, M. Kannan (2015) Influence of injection timing on DI diesel enginecharacteristics fueled with waste transformer oil. Alexandria Engineering Journal 54, 881-888.

Joonho Jeon, Sungwook Park (2015) Effects of pilot injection strategies on the flame temperature and soot distributions in an optical CI engine fueled with biodiesel and conventional diesel. Applied Energy 160:581-591.

Suresh K. Aggarwal, Xiao Fu, and Sameera Wijeyakulasuriya (2016) Effects of fuel reactivity and injection timing on diesel engine combustion and Emissions. International Journal Of Green Energy, vol. 13, NO. 5, 431-445.

P. Brijesh, A. Chowdhury, and S. Sreedhara (2015) The Simultaneous Reduction of NOx and PM Using UltraCooled EGR and Retarded Injection Timing in a Diesel Engine. International Journal of Green Energy 12, 347358.

Venkanna Krishnamurthy Belagur a \& Venkataramana Reddy Chitimini (2011) Influence of static injection timing on combustion, emission and performance characteristics of DI diesel engine fuelled with honne oil methyl ester. International Journal of Ambient Energy, 1-10, iFirst.

Venkanna K. Belagur and R.C. Venkataramana (2010) Injection Timing Impact on Calophyllum inophyllum linn oil (Honne Oil) / Diesel Fuelled Diesel Engine. V.K. Belagur and R.C. Venkataramana / International Energy Journal 11:145-152.

John B.LHeywood (1988) Internal Combustion Engine Fundamentals\|, McGraw-Hill Series in Mechanical Engineering, 198.

M. N Channappagoudra, Sunil Thaned, K. Ramesh, G.Manavendra (2013) Optimization of Combustion Chamber Geometry for a Direct Injection Diesel Engine:A Review. International Journal of Engineering Research \& Technology (IJERT), Vol. 2 Issue 11. 